\title{
農薬の環境リスク評価のための安全性試験と GLP\#
}

\author{
雜 賀修* \\ 株式会社日曹分析センター 小田原事業所 第 2 研究部
}

(2011 年 7 月 26 日受理)

Keywords: agro-chemicals, ecological risk assessment, GLP, OECD.

\section{はじめに}

農薬は意図的に環境中に放出される物質であり, 環境生 物への影響評価（生態影響リスク評価 Ecological Risk Assessment）は，環境リスク評価 Environmental Risk Assessment のひとつとして農薬の開発（有望候補化合物の効力評 価打よび安全性評価）ならびに登録審査において，ヒトの 健康への影響評価とともに重要な要件となっている．生態 影響リスク評価の目的は, 生態系（環境生物）への影響を 事前に予測し，生態系保全のための措置を講じることであ り，そのためには，環境生物を用いた毒性試験のみならず， 農薬の環境中での動態，作物中の残留，それらに影響する 物理化学的試験が必要となる。日米欧の生態影響リスク評 価では本質的に同じ評価方法が用いられているので，まず $\mathrm{EU}$ の評価法を例に生態影響リスク評価の基本的考え方と その特徴を整理し，次にリスク評価のために必要な試験を まとめ, 最後に試験の精度と信頼性を確保するシステムで ある GLP（Good Laboratory Practice）について，その役割と 意義について紹介したい.

\section{1. 農薬の生態リスク評価}

農薬はその国（あるいはその地域）ごとに審査され，登 録されなければ世にでることはできない，安全性の審査は 主にリスク評価に基づいて実施される。リスク評価の対象 は人と環境生物である。ここでは，環境生物（あるいは生 態系）へのリスク評価（生態影響リスク評価 Ecological Risk Assessment とも称する）について述べる.

生態影響リスク評価は，以下のように人に打けるリスク 評価とは異なる点がある。(1)ヒトのリスク評価の対象は七

\# 第 36 回大会シンポジウムを取りまとめた解説

* 干 250-0216 神奈川県小田原市高田 345

E-mail: o.saika@nippon-soda.co.jp

(C) Pesticide Science Society of Japan
ト（Homo sapiens Linnaeus, 1758）1 種のみであるが，生態 影響リスク評価の対象は多種であり, 同じ生物群であって も地域，国ごとに異なる種を用いることもある。(2)ヒトで は，対象となる生物を直接調べることができないため，主 に他の哺乳類（実験動物）を用いるが，生態影響リスク評 価では対象となる生物そのものを調べることができる。 (3) ヒトでは実験動物の結果をヒ卜に外挿することになるが, 生態影響リスク評価では対象となる生物が膨大であるため に代表的な種の結果から他種への影響を推定することにな る.したがって, どちらのリスク評価のおいても不確実係 数（使用場面によっては安全係数と呼ばれることもある） を用いて一定の安全域を確保することが必要となる。

リスク評価は, 農薬の有効成分扔よびその代謝物, 分解 物, 製剂について, 生物群ごとに急性/短期的影響および 長期/繁殖への影響について実施される。 リスク評価は段階

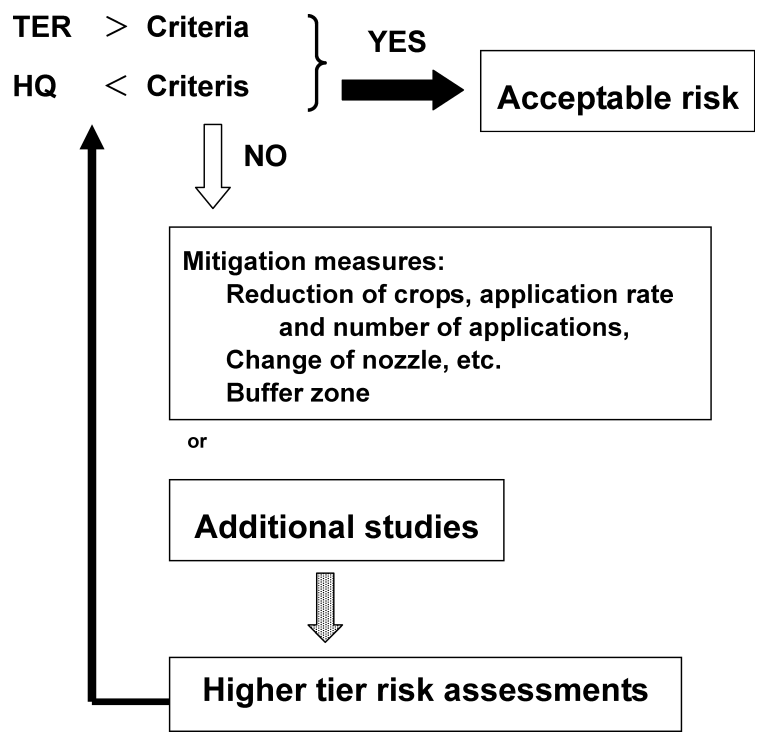

Fig. 1. Risk assessment with TER or HQ. $\mathrm{TER}=$ Toxicity-Exposure Ratio, $\mathrm{HQ}=$ Hazard Quotient. 
的に行なわれる。最初のリスク評価は生態毒性試験で得ら れた指標（半数影響濃度, 無影響量など）と暴露量（推定 摂取量，予測環境濃度など）を比較し，一定以上の安全域 が確保されればその時点で評価は終了となる（Fig. 1).リ スク評価は“相対評価”であり，単に毒性の強弱により決 まるものではなく，暴露量との関係により決定されるもの である。また，毒性指標と暴露量という定量的なデー夕を 比較する定量解析である。安全性が担保されないと判断さ れた場合には使用制限（例えば，Buffer zone〔周辺環境と の間に設ける農薬を散布しない区域」の設定，散布方法の 改善，散布回数の削減など）を設定するか，高次リスク評 価へ進む。高次リスク評価では，より現実に近い場面を想
定した検討（室内・野外のモデル試験，暴露濃度の精密な 算出）を行い，最終的には野外試験を実施する場合むある. 高次試験では，より現実的な場面を想定した試験であるた め，その結果に対する不確実係数はより小さなものとなる.

\section{2.リスク評価に必要な情報と試験}

リスク評価は推定暴露量と毒性指標を比較することに よって行われる。暴露量の予測には, GAP（Good Agricultural Practice : 対象作物, 散布量, 散布方法などの情報), 物理化学的性状（水溶解度, 水中安定性, 光安定性, 蒸気 圧, 比重, $\mathrm{p} K \mathrm{a}, \log P_{\mathrm{ow}}, K_{\mathrm{oc}}$ など）および環境化学のデー 夕（特に水，土，底質中での動態）が必須である.

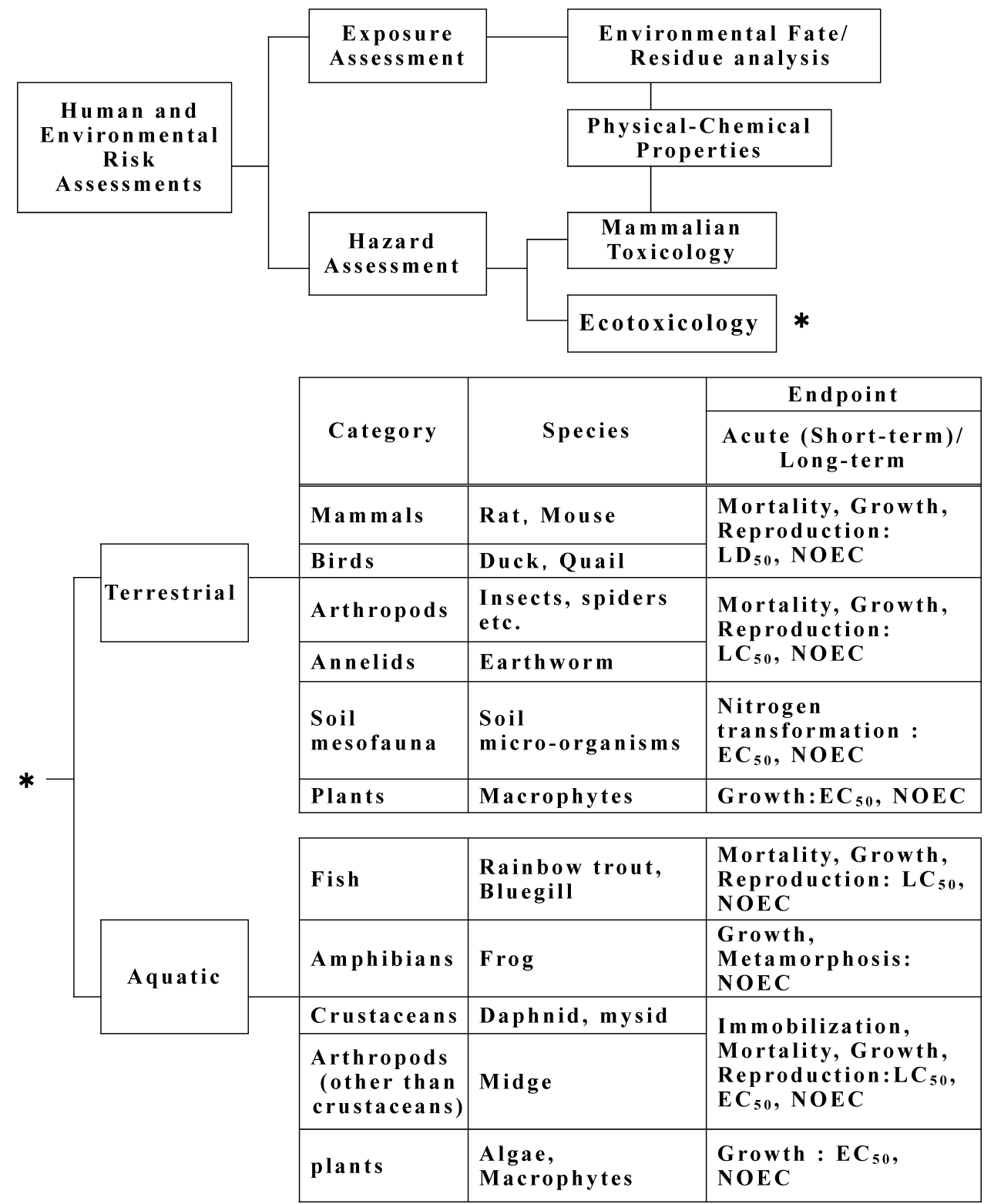

Fig. 2. Ecotoxicology studies for risk assessment. 
毒性の指標は, 哺乳類の毒性試験（陸生哺乳類のリスク 評価には，ヒトへのリスク評価のために実施される毒性試 験の結果を用いる）扔よび生態毒性試験の結果から得られ る。生態毒性試験の対象生物は, 陸生生物之水生生物に大 別され，ともに植物および動物（微生物から哺乳類まで） の広い生物群にわたっている（Fig. 2). リスク評価のため には，定量的な用量（暴露量）と反応性の把握，つまり， 定量的なエンドポイント（半数致死濃度〔Median Lethal Concentration: $\left.\mathrm{LC}_{50}\right]$, 半数影響濃度〔Median Effect Concentration: $\mathrm{EC}_{50}$ ，無影響量 〔No Observed Effect Concentration: NOEC〕など）を求めることが必要とされる。エンドポイ ントは，刺激性，変異原性の有無といった定性的なものて はなく，“LC $\mathrm{LC}_{50}$ は $1.0 \mathrm{mg} / \mathrm{L}$ である”というような定量的な ものである。したがって, 基本的には暴露量が測定されて いない試験の結果はリスク評価に使用できない，定量的で 正確な実験が必要であり，それも 1 回の本試験の実施によ り信頼性の高い結果を得ることが求められる。経済的，時 間的，動物愛護の観点から，効率的な予備試験は必要であ るが，不必要な試験，信頼性の低い試験を繰り返すことは 無意味であり，許されない。リスク評価に用いる試験は， 信頼性が確保され, 定量的に正確な結果が得られる試験で ある。

\section{GLP}

信頼性が確保された試験とは，どのようなものと考えら れているか? ?それは，資料・(記憶ではなく）記録から，試 験が再現でき, 試験の妥当性, 信頼性を検証できる試験で ある。この信頼性を確保するための基準のひとつが GLP （Good Laboratory Practice）基準 1,2) と呼ばれるものである. リスク評価に必要とされる試験（物理化学的性状，環境化 学，哺乳類毒性および生態毒性等）は基本的には GLP 基準 に則って実施されることが要求される。近年, 各国の GLP 基準は，国際的な協調が図られ，OECD の GLP 基準および 関連文書 ${ }^{3)}$ に従った基準となっている（Table 1)。GLP 基 準とは一回の試験で信頼性のあるデー夕を得るためのシス テムであり, SOP（標準操作手順書 Standard Operating Procedures), 試験計画書, 最終報告書, 生デー夕扔よび関連 資料で試験が再現できることを求めている。 その特徵は, (1)試験は十分な教育と訓練を受けた責任者之担当者により 実施され，その責任と職務が明確にされていること，(2)規 定された材料, 方法による試験の実施, (3)定量機器・器具 （天秤，ピペットなど）の精度確保，(4)試験の遂行と結果 は，第三者（信頼性保証部門）により査察され，その妥当 性が確認されていること，(5)これらが記録として保存され， 検証が必要な際には速やかに利用できることである。それ ぞれについていま少し詳細に述べる。

(1)人，何でもそうであるように，試験の信頼性の基本は
Table 1. OECD GLP Documents*

No. Title

1 OECD Principles of Good Laboratory Practice

2 Revised Guides for Compliance Monitoring Procedures for GLP

3 Revised Guidance for the Laboratory Inspections and Study Audits

4 Quality Assurance and GLP

5 Compliance of Laboratory Suppliers with GLP Principles

6 The Application of the GLP Principles to Field Studies

7 The Application of the GLP Principles to Short-term Studies

8 The Role and Responsibilities of the Study Director in GLP Studies

9 Guidance for the Preparation of GLP Inspection Reports

10 The Application of the Principles of GLP to Computerised Systems

11 The Role and Responsibilities of the Sponsor

12 Requesting and Carrying Out Inspections and Study Audits in Another Country

13 The Application of the GLP to Multi-Site Studies

14 The Application of the Principles of GLP to in vitro studies

15 Establishment and Control of Archives with the Principles of GLP

* From "Download” of http://www.jsqa.jp/

人である，試験は十分な教育と訓練を受けた担当者と 結果を評価できる責任者により実施する。担当者は十 分な試験の経験, 実験操作の教育訓練を受けている必 要がある（例えば，メスフラスコとメスシリンダーの 用途の理解，観察する生物の異常之正常の区別ができ る).教育・訓練・理解の不足している人に試験を担当 させてはいけない，試験担当者の選定も含め試験の実 施と結果のすべてに責任を負うのが試験責任者である. (2)規定された材料と方法による試験の実施：試験に用い る材料, 試験操作はあらかじめ規定し, 人による操作 の違い，䛊差を最小にすることが求められる。これら は試験計画書に盛り込まれ, 試験材料, 計画操作の事 前確認, 試験内容, 操作の理解に用いられる. 被験物 質, 試薬はその純度（あるいは組成）・安定性・有効期 限を必ず規定, 確認し, SOP（標準操作手順書 Standard Operating Procedures), 試験計画書により統一され た方法で実験操作を行う。

(3)定量機器・器具の精度確保, 間違いない操作：例えば, 天秤はその試験の精度に十分対応したものを使用し， 正常に作動していることを確認する（例えば，基準分 
銅によるキャリブレーション，水平確認，污れていな いか (コンタミの防止), 電源を入れてから測定までの 時間，室温などが適切か)，科量值は間違いがないこと が測定後確認できるように記録（プリントアウト）す る。また, ピペット類は，機器と担当者の精度，定期 点検の状況を事前に確認する（これらも試験責任者の 責務である).

(4)試験の実施と結果（妥当性）の確認：第三者（信頼性 保証部門）により査察を実施する。査察は，データの チェックだけではなく，担当者の教育訓練状況，機器 の点検状況が妥当であったか否かも対象となる。デー 夕のチェックは試験実施者がデータのチェックを実施 したことを確認する（データをチェックするのは試験 実施者の義務である)。信頼性保証の観点からの生態毒 性試験の特徵については QA 研究会の資料 ${ }^{4 ） に ま と め ~}$ られている。

(5)記録と保存：試験結果だけではなく, 試験計画書, 生 データ，SOP，教育記録，通信記録，被験物質に関す る情報，機器の使用記録・点検記録，最終報告書な ど, 試験を最初（計画）から最後（最終報告書完成） まで再構築できるように必要なすべての資料を試資料 保管施設に保存する。

以上，GLP 試験について述べたが，GLP は何も特別なこと を要求しているわけではない，ただ，“当たり前のことを ちゃんとやって，それを記録に残す”ことを要求している だけである.

環境影響試験においても GLP 基準の適用は基本的に同じ である，室内で実施する生態毒性試験は哺乳類の毒性試験 と同じであり，生物・試験系の維持（飼育）・管理，正常， 異常の判定，供試の可否など，試験担当者の経験，熟練が 必要となる項目も多い。また，野外試験では，天候，供試 生物の状況など計画どおりには行かない（カレンダーで計 画が立てられない）こともあり，SDの判断，能力に依存す る事項，人による差がでやすい項目もある。 また，複数場 所試験として, 生物試験：A 研究所, 被験物質分析：B 機 関，タンパク定量：C大学とふたつ以上の試験機関がひと つの試験として，運用されること屯少なくない。このよう な試験では，試験目的と試験内容に関する相互理解，試験 実施についての密接な連絡体制の構築が重要である.

\section{おわりに}

生態影響リスク評価は，GLPにより信頼性が保証された
定量的試験結果に基づき，農薬の散布方法，環境動態を考 慮して実施される総合評価であり, 各国の農業形態, 環境 などにより異なるものとなる。また，現実的な場面を想定 した高次試験によりリスクを精緻化することも必要になる. このような試験では試験目的を明確にしてその目的に応じ た試験を設計することが重要である。しかしながら，評価 の考え方の指針はあるが，試験方法の具体的なガイドライ ンはない。したがって，試験設計と実施には，その試験に 携わる者の能力が大きく問われることになる，高次試験を 設計するには，抱負な知識と経験が必要であり，一朝一夕 に高次試験を任すことができる人材は育たない。このよう な人材を育成するには，地道で長期的な育成計画が不可欠 である。

余談ではあるが，“試験ガイドラインのない試験でも GLP 試験として実施できる”（20 世紀末の GLP 基準に馴染みが ない頃には，試験ガイドラインがないと GLP 試験ができな いと信じている人をみかけたが，もう 21 世紀，そのような 人はいないと思うが念のため). GLP の理念を十分理解して いれば，どのような試験も GLP 試験として実施できる. GLP から外れた部分は, そのことを記録して, 報告書に記 載すればよいのである（そうすれば，後日，そのことが試 験の信頼性に影響したか否かを検証できる)。必要な情報が 正確に記録された試験は，どのような試験（たとえ失敗した 試験）であってもその精度に応じて役立てることができる.

\section{引 用 文 献}

1) http://www.acis.famic.go.jp/glp/6283/6283 号局長通知別添. pdf

2) http://www.env.go.jp/chemi/kagaku/hourei/tuuchi/glp02.pdf

3) 日本 QA 研究会ホームページ http://www.jsqa.jp/

4) 日本 QA 研究会（2004）GLP-QA 活動のためのガイドブッ ク.
略 歴
雜賀 修（さいか おさむ）
生年月日：1955 年 9 月 17 日
最終学歴: 北海道大学大学院水産科学研究科博士課程終了
研究テーマ：化学物質の水生生物に対する影響の比較生物学的 解析
趣＼cjkstart味：スクーバダイビング 